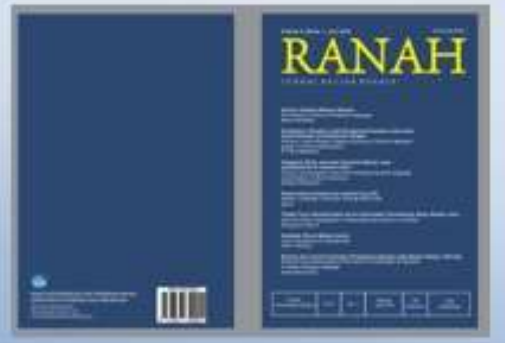

\title{
MEDAN MAKNA AKTIVITAS TANGAN DALAM BAHASA SASAK DIALEK NGENO-NGENE
}

\author{
Meaning Fields Activities Hands in \\ Languages of Ngeno-Ngene Dialek
}

\author{
Hubbi Saufan Hilmi ${ }^{1}$, Fabio Testy Ariance Loren ${ }^{2}$ \\ ${ }^{1}$ Universitas Khairun Ternate \\ ${ }^{2}$ Universitas Maritim Ali Raja Haji \\ hubbyshilmy@gmail.com,fabioloren10@gmail.com
}

\begin{abstract}
Abstrak
Penelitian ini bertujan untuk mendeskripsikan komponen medan makna aktivitas tangan dalam bahasa Sasak dialek ngeno-ngene di Desa Labuhan Haji, Kabupaten Lombok Timur. Metode penelitian yang digunakan dalam penelitiaan ini ialah metode deskriptif dengan bentuk kualitiatif. Data dalam penelitian ini didapatkan dari 30 sampel penutur asli bahasa Sasak dialek ngeno-ngene dari dua dusun yang berbeda dalam satu desa, sementara itu data dalam penelitian ini berupa data lisan. Teknik pengumpulan data dalam penelitian ini menggunakan metode cakap dan simak. Hasil penelitian menunjukkan bahwa medan makna aktivitas tangan dalam bahasa Sasak dialek ngenongene memiliki lima puluh empat leksem dan dikelompokkan berdasarkan komponen makna yang ada di dalamnya menjadi sembilan belas submedan makna aktivitas tangan dalam bahasa Sasak dialek ngeno-ngene.
\end{abstract}

Kata-kata kunci: medan makna, aktivitas tangan, bahasa Sasak.

\begin{abstract}
This research aims to describe the components of the meaning of hand activities in the village of Labuhan Haji East Lombok district. The research method used in this research is a descriptive method with a qualitative form. The data in this study was obtained from 60 samples of native Sasak language ngeno-ngene dialect from two different hamlets in one village, meanwhile, the data in this study is oral data. The data technique in this study use proficient methods and see. The rseults of this study showed that the meaning of the activity field in Sasak dialect has fifty four lexemes and grouped based on the meaning of component that is in it to nineteen subterrain meaning hand activity in Sasak dialect ngeno-ngene.
\end{abstract}

Keywords: meaning field, hand activity, Sasak language

How to Cite: Hilmi, Hubbi Saufan dan Fabio Testy Ariance Loren. (2019). Medan Makna Aktivitas Tangan dalam Bahasa Sasak Dialek Ngeno-Ngene, Ranah: Jurnal Kajian Bahasa, 8 (1), 53-75. doi: https://doi.org/10.26499/rnh.v8i1.625 


\section{PENDAHULUAN}

Bahasa Sasak merupakan bahasa daerah yang digunakan oleh masyarakat suku Sasak di pulau Lombok Nusa Tenggara Barat. Bahasa Sasak oleh Paridi (1996: 1) digolongkan ke dalam lima dialek, yakni dialek meno-mene, dialek ngeno-ngene, dialek meriak-meriku, dialek keto-kete, dan dialek meto-mete, sementara itu Mahsun (2006: 61) mengungkapkan bahwa bahasa Sasak memiliki empat dialek besar, yaitu dialek Bayan $(a-a)$, dialek Pujut ( $a-e)$, dialek Selaparang $(e-e)$, dialek Aiq Bukak (a-o). Azhar (1996: 1) menjelaskan bahwa dialek ngeno-ngene yang sering disebut juga dialek Selaparang digunakan oleh sebagaian besar masyarakat Lombok.

Bahasa Sasak merupakan salah satu aset kekayaan bangsa, kajian tentang makna dalam bahasa Sasak dialaek ngeno-ngene ini menjadi salah satu upaya melestarikan bahasa daearah. Mahsun (dalam Toba, 2016: 88) mengungkapkan bahwa upaya memelihara bahasa daerah perlu dilakukan karena sikap penutur bahasa daerah yang kurang positif terhadap bahasa daerahnya sendiri.

Penelitian ini cukup relevan dengan penelitian yang dilakukan oleh Lalu Mohamad Johandipada tahun 2017 dengan judul An Analysis Of Sasak Syntactic Structure On The Forms Of Passivization As Used In Ngeno-Ngene Dialect At Rarang Village Of East Lombok, membahas struktur sintaksis bahas Sasak dialek ngeno-ngene di desa Rarang kabupaten Lombok Timur. Hasil penelitiannya menyebutkan bahwa dalam bahasa Sasak dialek ngeno-ngene ditemukan dua jenis konstruksi pasif, yaitu konstruksi kanonik dan adversatif. Persamaan penelitian ini dengan penelitian yang dilakukan Lalu Mohamad Johandi ialah sama-sama meneliti objek kajian bahasa yang sama, yakni bahasa Sasak dialek ngeno-ngene.

\section{LANDASAN TEORI}

Semantik adalah cabang ilmu linguistik yang membahas arti atau makna (Verhaar, 2012: 13). Salah satu bagian dalam sistem semantik ialah medan makna. Pateda (2010: 257) mengungkapkan bahwa medan makna merupakan seperangkat makna yang mempunyai komponen umum yang sama atau saling terjalin. Chaer (2012: 315-316) lebih lanjut menerangkan bahwa medan makna (semantic domain, semantic field) atau medan leksikal adalah seperangkat unsur leksikal yang maknanya saling berhubungan karena menggambarkan bagian dari bidang kebudayaan atau realitas dalam alam 
semesta tertentu. Sebelumnya, Kridalaksana (2011: 151) juga mengungkapkan bahwa medan makna adalah bagian dari sistem semantik bahasa yang menggambarkan bagian dari bidang kehidupan atau realitas dalam alam semesta tertentu dan yang direalisasikan oleh seperangkat unsur leksikal yang maknanya berhubungan.

Komponen makna atau komponen semantik (semantic feature, semantic property, atau semantic marker) sebagaiman dijelaskan Chaer (2013: 114) mengajarkan bahwa setiap kata atau unsur leksikal terdiri dari satu atau beberapa unsur yang bersama-sama membentuk makna kata atau unsur leksikal tersebut. Semisalnya, kata ayah mengandung komponen makna atau unsur makna: + manusia + dewasa + jantan dan +kawin; dan kata ibu mengandung komponen makna: + manusia + dewasa -jantan dan +kawin.

Berdasarkan pendapat ahli tersebut, maka dapat disimpulkan bahwa medan makna ialah bagian sistem semantik (makna) yang secara keseluruhan menggambarkan realitas kehidupan dan mempunyai komponen makna sama atau saling terjalin satu dan yang lainnya.

Aktivitas tangan dalam penelitian ini dibatasi pengertiannya berdasarkan pada pengertian aktivitas dan tangan. Sriyono (dalam Chaniago, 2010: 1) bahwa aktivitas ialah segala kegiatan yang dilaksanakan baik secara jasmani maupun rohani, sementara itu tangan ialah anggota tubuh manusia dari siku sampai ke ujung jari tangan. Batasan aktivitas tangan dalam bahasa Sasak dialek ngeno-ngene di desa Labuhan Haji dalam penelitian ini ialah kemampuan anggota badan dari siku sampai ujung jari dalam melakukan aktivitasnya tidak dibantu dengan anggota badan.

\section{METODE PENELITIAN}

Metode yang digunakan dalam penelitian ini adalah metode deskriptif. Populasi dalam penelitian ini ialah penutur asli bahasa Sasak yang mendiami wilayah desa Labuhan Haji. Pemilihan sampel penelitian dalam penelitian disesuaikan dengan sembilan syarat pemilihan sampel informan menurut Mahsun (2006: 34-35). Berdasarkan kedua hal tersebut, maka dalam penelitian ini diambil populasi dan sampel penelitian dari dua dusun dengan pengguna bahasa Sasak dialek ngeno-ngene terbanyak, yaitu dusun Montong Meong dan dusun Dasan Esot dengan sampel penelitian masing-masing dusun berjumlah 30 orang. 
Data dalam penelitian ini berupa data lisan yakni sejumlah leksem bahasa Sasak dialek ngeno-ngene di desa Labuhan Haji yang mengandung makna aktivitas tangan. Teknik pengumpulan data dalam penelitian ini menggunakan metode cakap dan simak. Analisis data yang digunakan dalam penelitian ini ialah metode introspeksi (Sudaryanto dalam Mahsun, 2006: 102). Metode analisis data dalam penelitian ini dilakukan dengan cara menggunakan teknik analisis komponen. Penyajian hasil data dalam penelitian ini disajikan melalui dua cara, yakni informal dan formal (Sudariyanto dalam Mahsun 2006: 116).

\section{PEMBAHASAN}

Adapun beberapa komponen submedan makna aktivitas tangan dalam bahasa Sasak dialek ngeno-ngene di Desa Labuhan Haji, Kabupaten Lombok Timur yang didasarkan pada tujuan aktivitas tangannya ialah sebagai berikut.

1) Medan makna aktivitas tangan "memegang"

Medan makna "memegang" memiliki bentuk dasar, yakni pegang. Leksem "pegang" memiliki komponen makna, yakni gerakan tangan menggenggam + sasaran + motivasi mengenggam/memegang sasaran. Bahasa Sasak dialek ngenongene di Desa Labuhan Haji memiliki delapan leksem untuk aktivitas tangan ini. Keempat leksem tersebut ialah sebagai berikut.

$\begin{array}{ll}\text { entik } & \text { 'pegang', } \\ \text { regem } & \text { 'genggam' }\end{array}$

Leksem entik 'pegang' adalah leksem dasar dan mempunyai bentuk aktif, yakni ngentik 'memegang'. Leksem entik 'pegang' memiliki komponen makna, yakni gerakan tangan yang dilakukan jari-jari untuk memegang suatu benda (sasaran). Berikut contoh penggunaannya dalam bahasa Sasak dialek ngeno-ngene di Desa Labuhan Haji.

Entik tas ne juluk semendak, ku joq kamar mandi juluk.

'Pegang dulu tas ini sebentar, saya mau ke kamar mandi dulu.'

Leksem regem memiliki komponen makna yang mencakup aktivitas jari-jari yang menekan ke telapak tangan dan mencakup sasaran dalam genggaman. Berikut contoh penggunaan leksem regem dalam kalimat.

Regem kepeng logam ini teguk-teguk, agek ndakne terik.

'Genggam erat uang logam itu, agar tidak jatuh.' 
Submedan makna aktivitas tangan untuk 'memegang' dalam bahasa Sasak dialek ngeno-ngene di Desa Labuhan Haji memiliki dua leksem. Dilihat dari komponen makna yang dimilikinya, leksem entik 'pegang' merupakan superordinat dalam kelompok ini. Ciri semantik penggolong yang dimiliki oleh leksem entik dan ciri semantik yang dimiliki oleh leksem bawahannya ialah adanya komponen makna gerakan tangan + gerakan jari + sasaran + motivasi memegang sasaran.

2) Medan makna aktivitas tangan "menangkap"

Medan makna aktivitas tangan "menangkap" memliliki komponen makna, yakni gerakan tangan + sasaran + motivasi untuk memperoleh/mendapatkan sasarannya. Medan makan aktivitas tangan “menangkap' ini dalam bahasa Sasak dialek ngeno-ngene ialah sebagai berikut.

$\begin{array}{ll}\text { bau } & \text { 'tangkap' } \\ \text { turkep } & \text { 'tangkap' }\end{array}$

Leksem bau 'tangkap' memiliki komponen makna, yakni gerakan kedua tangan secara bersamaan + mengarah kepada gerak sasaran + motivasi mendapatkan sasaran. Berikut penggunaan leksem beu dalam kalimat.

Nendek beu bebek kance manek si' pute' ino.

'Jangan tangkap bebek dan ayam yang putih itu.'

Leksem turkep 'tangkap' memiliki komponen makna, yakni gerakan tangan dengan telapak tangan terbuka + sasaran berada di sebuah objek/berada di bawah + motivasi mendapatkan sasaran. Berikut penggunaannya dalam bahasa Sasak dialek ngeno-ngene.

Cobak turkep kedara siq leq julun bale ino.

Coba tangkap burung dara yang ada di depan rumah itu.'

Submedan makna aktivitas tangan untuk "menangkap" dalam bahasa Sasak dialek ngeno-ngene di Desa Labuhan Haji memiliki dua leksem. Kedua leksem tersebut dalam kelompok ini tidak memiliki leksem superordinat, akan tetapi memiliki makna yang hampir bersinggungan. Kelompok ini termasuk ke dalam leksem superordinat zero. Ciri semantik dalam kelompok ini ialah adanya komponen makna gerakan tangan + sasaran + motivasi mendapatkan sasaranny $a$.

3) Medan makna aktivitas tangan "menyentuh"

Medan makna aktivitas tangan "menyentuh" memiliki kata dasar "sentuh". Kata dasar "sentuh" memiliki komponen makna gerakan tangan dengan jari atau 
sebagian jari yang dilakukan secara perlahan pada sasaran dan dilakukan karena adanya motivasi merasakan (keberadaan) sasaran dan dalam waktu yang cukup singkat. Medan makna aktivitas tangan "menyentuh" dalam bahasa Sasak dialek ngeno-ngene di Desa Labuhan Haji memiliki empat leksem. Keempat leksem tersebut ialah sebagai berikut.

$\begin{array}{ll}\text { jelut } & \text { 'sentuh' } \\ \text { jolet } & \text { 'colek' } \\ \text { gorap } & \text { 'usap' } \\ \text { dore } & \text { 'raba' }\end{array}$

Leksem jelut 'sentuh' memiliki komponen makna gerakan ujung jari ke sasaran dengan lembut/pelan dan dalam waktu yang singkat. Penggunaannya dalam bahasa Sasak dialek ngeno-ngene di Desa Labuhan Haji sebagai berikut.

Nendek jelut aik ini, soalne masihne panas.

'Jangan sentuh air itu, karena masih panas.'

Leksem jolet 'colek' memiliki komponen makna gerakan ujung jari tangan yang dilakukan kepada sasaran dengan tujuan untuk mendapat perhatian sasaran yang disentuhnya dan sasarannya biasanya merupakan manusia/makhluk hidup. Berikut contoh penggunaannya dalam bahasa Sasak dialek ngeno-ngene.

Kaget aku pas mek jolet ngonek no.

'Saya kaget saat kamu colek tadi.'

Leksem gorap 'usap' memiliki komponen makna aktivitas semua jari dan sekaligus telapak tangan kepada sasarannya dengan cara halus dan lembut secara berulang-ulang. Berikut contoh penggunaannya dalam bahasa Sasak dialek ngenongene.

Ye gorap meong ino lonto lekan onek klema'.

'Dia usap kucing itu saja dari tadi pagi.'

Leksem dore 'raba' memiliki komponen makna gerakan seluruh jari tangan ke sasarannya dan dengan motivasi untuk merasakan keberadaan sasarannya tersebut. Berikut contoh penggunaannya dalam bahasa Sasak dialek ngeno-ngene.

Cobe' mek dore remot tv no le' bawa' kasur ini, sang le' tono taokne.

Coba kamu raba remot tv di bawah kasur itu, mungkin dia di sana.'

Submedan makna aktivitas tangan untuk menyentuh dalam bahasa Sasak dialek ngeno-ngene di Desa Labuhan Haji memiliki empat leksem. Leksem superordinat dalam kelompok ini ialah jolet 'sentuh'. Ciri semantik penggolong 
yang dimiliki oleh leksem jolet 'sentuh' dan ciri sematik yang dimiliki oleh leksem bawahan lainnya ialah memiliki komponen makna aktivitas gerakan tangan + gerakan jari-jari tangan + sasaran + tempo waktu singkat + motivasi merasakan keberadaan sasaran.

4) Medan makna aktivitas tangan "mengambil"

Mengambil memiliki komponen makna, yakni aktivitas gerakan tangan menuju sasaran, dan disertai dengan adanya motivasi untuk mendapatkan sasarannya. Medan makna aktivitas tangan "mengambil" dalam bahasa Sasak dialek ngeno-ngene, di antaranya ialah sebagai berikut.

$\begin{array}{ll}\text { bait } & \text { 'ambil' } \\ \text { embun } & \text { 'pungut' } \\ \text { jeput } & \text { 'jumput' } \\ \text { embot } & \text { 'cabut' } \\ \text { jepit } & \text { 'jepit' } \\ \text { jolak } & \text { 'gapai' }\end{array}$

Leksem bait 'ambil' memiliki komponen makna gerakan tangan + gerakan selurus jari tangan + sasaran + motivasi untuk mendapatkan sasaran. Berikut contoh penggunaannya.

Baitang aku batek leq paon no juluk.

'Ambilkan dahulu saya parang di dapur itu.'

Leksem embun 'pungut' memiliki komponen makna gerakan tangan + gerakan jari tangan ke arah bawah + sasaran berada di bagian bawah dari tubuh+ motivasi mendapatkan sasaran. Berikut contoh penggunaannya.

Enteh te ngembun reronggo leq mudin masjid no, agekne bersih.

'Ayo kita memungut sampah di belakang masjid itu, agar bersih.'

Leksem jeput 'jemput, jumput' memiliki komponen makna gerakan tangan + ujung jari tangan yang dirapatkan/dikatupkan + sasaran + motivasi untuk mendapatkan sebagian dari sasaran tersebut. Berikut contohnya.

Jeputang dirik be tembako ni.

'Ambillah (jumputlah) sendiri tembakau itu.'

Leksem embot 'cabut' ialah memilki komponen makna gerakan tangan + gerakan seluruh jari tangan menggenggam erat + sasaran dalam cakupan genggaman + sasaran tertanam dalam tanah (objek tertentu) + motivasi untuk mendapatkan sasaran. Berikut contohnya. 
Sai nyabut tiang kendangan ino?

'Siapa yang mencabut tiang jemuran itu?'

Leksem jepit 'jepit' memiliki komponen makna gerakan tangan yang dilakukan dengan dua jari + sasran dalam cakupan dan realtif kecil + motivasi untuk mendapatkan sasaran. Penggunaan leksem jepit dapat dilihat pada contoh kalimat berikut.

Jepit polpen si leq sedi mek ini.

'Jepit bolpoin yang ada di sampingmu itu.'

Leksem jolak 'gapai' memiliki komponen makna gerakan tangan yang diulurkan mengarah ke sasaran + sasaran + sasaran berada pada posisi jauh (atas) dari tubuh + motivasi untuk mendapatkan sasaran tersebut. Berikut contoh penggunaannya.

Nedekde tao ke jolak buak nyambuk ino?

'Tidak bisakah kamu menggapai buah jambu itu?'

Submedan makna aktivias tangan untuk mengambil dalam bahasa Sasak dialek ngeno-ngene di Desa Labuhan Haji memiliki tujuh leksem. Leksem yang menjadi superordinatnya ialah leksem bait 'ambil'. Ciri semantik penggolong yang dimiliki leksem bait 'ambil' dan ciri semantik kelompoknya ialah adanya komponen makna gerakan tangan + sasaran + mendapatkan sasaran.

5) Medan makna aktivitas tangan "membawa"

Medan makna aktivitas tangan "membawa" memiliki komponen makna gerakan tangan + sasaran dalam cakupan + motivasi mendapatkan dan memindahkan sasaran. Bahasa Sasak dialek ngeno-ngene di Desa Labuhan Haji memiliki dua leksem "membawa", di antaranya ialah sebagai berikut.

$\begin{array}{ll}\text { jauk } & \text { 'bawa' } \\ \text { bentek } & \text { 'jinjing', }\end{array}$

Leksem jauk 'bawa' memiliki komponen makna gerakan tangan + sasaran dalam cakupan jemari tangan + motivasi untuk memindahkan objek/sasarannya. Berikut contoh penggunaannya dalam kalimat.

Inaq jauk adik milu lalo joq peken.

'Ibu membawa adik pergi ke pasar.'

Leksem bentek 'jinjing' memiliki komponen makna gerakan tangan menjulur ke arah bawah + gerakan jari-jari tangan + sasaran (relatif kecil dan ringan) dalam 
cakupan jemari tangan + sasaran tetap di bagian bawah tubuh + motivasi memindahkan sasaran. Berikut contoh penggunaannya.

Kan mek bentek sepatu mek Udin?

'Kenapa kamu jinjing sepatumu Udin?'

Submedan makna aktivitas tangan untuk "membawa" dalam bahasa Sasak dialek ngeno-ngene di Desa Labuhan Haji memiliki dua leksem. Leksem yang menjadi superordinatnya ialah leksem jauk 'bawa'. Ciri semantik penggolong yang dimiliki leksem tersebut dan kelompoknya ialah adanya komponen makna gerakan tangan + sasaran + motivasi memindahkan sasaran.

6) Medan makna aktivitas tangan "meletakkan"

Medan makna aktivitas tangan "meletakkan" memiliki komponen makna, yaitu gerakan tangan + sasaran dalam cakupan + motivasi untuk menempatkan sasaran pada suatu lokasi yang telah ditentukan. Bahasa Sasak dialek ngeno-ngene di Desa Labuhan Haji memiliki tiga leksem di antaranya ialah sebagai berikut.

$\begin{array}{ll}\text { tolo' } & \text { 'taruh' } \\ \text { selitang } & \text { 'selipkan' } \\ \text { talet } & \text { 'tanam' }\end{array}$

Leksem tolo' 'taruh' memiliki komponen makna gerakan tangan + sasaran dalam cakupan + memenempatkan sasaran pada lokasi tertentu. Berikut adalah contoh penggunaannya.

Tolo'ang aku rokok ni leq meja julu.

'Taruhkan/letakkan saya rokok itu di meja depan.'

Leksem selitang 'selipkan' memilki komponen makna gerakan tangan atau jari tangan + sasaran (realtif kecil dan tipis) + motivasi meletakkan sasaran di antara benda-benda yang lain. Berikut contoh penggunaannya.

Selitang aku awis ino leq pager ino.

'Selipkan saya sabit itu di pagar/dinding itu.'

Leksem talet 'tanam' memiliki komponen makna gerakan tangan dan jari tangan ditekuk + sasaran dalam cakupan + motivasi menempatkan sasaran pada lokasi tertentu, pada umumnya berupa sebuah lubang pada tanah. Berikut contohnya.

Udin, jemak talet pade no leq bangket.

'Udin, besok tanam padi itu di sawah.' 
Submedan makna aktivitas tangan untuk meletakkan dalam bahasa Sasak dialek ngeno-ngene di Desa Labuhan Haji memiliki tiga leksem. Leksem-leksem pada kelompok ini mempunyai makna yang mirip atau bersinggungan antara satu dengan yang lainnya, namun kelompok ini tidak memiliki leksem yang menjadi superordinat, dengan kata lain submedan ini merupakan kelompok superordinat zero.

7) Medan makna aktivitas tangan "memberi"

Medan makna aktivitas tangan memberi memiliki komponen makna, yakni gerakan tangan atau jari-jari + sasaran dalam ketercakupannya + motivasi untuk mengarahkan dan memindahkan sasaran kepada lawan. Bahasa Sasak dialek ngenongene di Desa Labuhan Haji memiliki dua leksem yang memiliki makna sama. Kedua leksem tersebut di antaranya ialah sebagai berikut.

$\begin{array}{ll}\text { beang } & \text { 'beri' } \\ \text { jonjo' } & \text { 'beri' }\end{array}$

Leksem beang 'beri' memiliki komponen makna, yakni gerakan tangan beserta jari-jari yang diulurkan + sasaran dalam cakupan + motivasi mengarahkan dan memindahkan sasaran kepada lawan. Penggunaan leksem tersebut dalam bahasa Sasak dialek ngeno-ngene dapat dilihat pada contoh berikut.

Beang loq Amir sepatu ine!

'Beri si Amir sepatu ini!'

Leksem jonjo' 'beri' memiliki komponen makna, yakni gerakan tangan beserta jari tangan + sasaran dalam cakupan + motivasi mengarahkan dan memindahkan sasaran kepada lawan yang berada di atas atau di bawah posisi tubuh. Berikut penggunaannya dalam kalimat bahasa Sasak dialek ngeno-ngene.

“Jonjo'ang ite palu ini”, ngkat loq udin lekan atas genteng.

“"Beri saya palu itu”, kata si Udin dari atas genteng.'

Submedan makna aktivitas tangan untuk "memberi" dalam bahasa Sasak dialek ngeno-ngene di Desa Labuhan Haji memiliki dua leksem. Leksem yang menjadi superordinatnya ialah leksem beang 'beri'. Ciri semantik penggolong yang dimiliki leksem tersebut dan leksem lainnya ialah adanya komponen makna gerakan tangan + sasaran dalam cakupan + motivasi mengarahkan dan memindahkan sasaran kepada lawan. 
8) Medan makna aktivitas tangan "menerima"

Medan aktivitas tangan "menerima" memiliki komponen makna, yakni gerakan tangan yang diulurkan + sasaran belum dalam cakupan + motivasi mendapatkan sasaran tersebut. Hanya satu leksem dalam bahasa Sasak dialek ngeno-ngene yang menyatakan medan makna aktivitas tangan "menerima" ialah sebagai berikut.

terima' 'terima'

Leksem terima' 'terima' memiliki komponen makna gerakan menjulurkan tangan + sasaran belum dalam cakupan + motivasi mendapatkan sasaran. Berikut contoh penggunaannya dalam bahasa Sasak dialek ngeno-ngene di Desa Labuhan Haji.

Ndkte kanggo terima' kepeng kadu ima kira.

'Tidak boleh menerima uang menggunakan tangan kiri.'

Submedan makna aktivitas tangan untuk "menerima" dalam bahasa Sasak dialek ngeno-ngene di Desa Labuhan Haji hanya memiliki satu leksem saja, yakni terima' 'terima', sehingga secara otomatis submedan makna aktivtas tangan dalam bahasa Sasak dialek ngeno-ngene untuk 'menerima' tidak memiliki leksem superordinat serta leksem bawahan. Ciri semantik penggolong yang dimiliki leksem tersebut sendiri ialah adanya komponen makna gerakan menjulurkan tangan + sasaran belum dalam cakupan + motivasi mendapatkan sasaran.

9) Medan makna aktivitas tangan "membuka"

Medan makna "membuka" memiliki komponen makna gerakan tangan dengan seluruh jari + sasaran dalam cakupan + motivasi untuk menggerakkan sasaran. Bahasa Sasak dialek ngeno-ngene di Desa Labuhan Haji juga memiliki beberapa leksem, yakni sebagai berikut.

$\begin{array}{lc}\text { buka' } & \text { 'buka' } \\ \text { lokes } & \text { 'kupas' } \\ \text { pengewak } & \text { 'buka lebar-lebar' }\end{array}$

Leksem buka' 'buka' memiliki komponen makna gerakan tangan dengan seluruh jari + seluruh sasaran dalam cakupan + motivasi untuk menggerakkan sasarannya. Berikut contoh penggunaannya.

Buka' be tutup kotak ino, be taokde so apa isi ne.

'Buka saja tutup kotak itu, pasti Anda tahu apa isinya.' 
Leksem pengewak 'buka lebar-lebar' memiliki komponen makna gerakan tangan dengan seluruh jari + seluruh sasaran dalam cakupan + motivasi menggerakkan seluruh sasarannya. Berikut contoh penggunaannya dalam kalimat.

Pengewakbe lawang ini, agekne tao' arak dengan leq dalem.

'Buka lebar-lebar saja pintu itu, agar tahu bahwa ada orang di dalam.'

Leksem lokes 'kupas' memiliki komponen makna gerakan tangan menggunakan gerakan jari (ibu jari dan jari telunjuk) + sasaran dalam cakupan + motivasi membuka bagian dari objek tersebut. Penggunaan dalam kalimat dapat dilihat pada contoh kalimat berikut.

Lokes julu' ampas jerek ino sampe' bersi, ampok kaken ye.

'Kupas terlebih dahulu kulitnya jeruk itu hingga bersih, baru setelah itu dimakan.'

Submedan makna aktivitas tangan untuk "membuka" dalam bahasa Sasak dialek ngeno-ngene di Desa Labuhan Haji memiliki tiga leksem. Leksem buka' 'buka' menjadi leksem superordinat dalam kelompok ini. Ciri semantik dalam kelompok ini ialah adanya komponen makna gerakan tangan + sasaran dalam cakupan + motivasi menggerakkan sasaran dengan tujuan menjadikan sasaran terbuka.

10) Medan makna aktivitas tangan "menutup"

Medan makna aktivitas tangan "menutup" memiliki komponen makna gerakan tangan + sasaran dalam cakupan + motivasi untuk meniadakan/ menghilangkan bagian yang terbuka/berlubang pada sasaran. Bahasa Sasak dialek ngeno-ngene di Desa Labuhan Haji mengenal satu leksem, yakni simpet 'tutup'. Simpet 'tutup' memiliki komponen makna, yakni gerakan tangan + sasaran dalam cakupan + motivasi meniadakan lubang atau bagian yang terbuka pada sasaran. Berikut contoh penggunaannya dalam bahasa Sasak dialek ngeno-ngene.

Simpet lawang ini mun mek sugul bekedek.

'Tutup pintu itu kalau kamu keluar bermain.'

Submedan makna aktivitas tangan untuk "menutup" dalam bahasa Sasak dialek ngeno-ngene di Desa Labuhan Haji hanya memiliki satu leksem saja, yakni simpet 'tutup', sehingga secara otomatis submedan makna aktivitas tangan dalam bahasa Sasak dialek ngeno-ngene untuk 'menutup' tidak memiliki leksem superordinat dan leksem bawahan. Ciri semantik penggolong yang dimiliki leksem 
tersebut sendiri ialah adanya komponen makna gerakan tangan + sasaran dalam cakupan + motivasi meniadakan lubang atau bagian yang terbuka pada sasaran.

11) Medan makna aktivitas tangan "menarik'

Medan makna aktivitas tangan "menarik" memiliki komponen gerakan tangan yang menjulur ke arah depan kemudian kembali ke arah belakang + sasaran dalam cakupan + motivasi menggerakkan sasaran. Bahasa Sasak dialek ngenongene memiliki tiga aktivitas tangan untuk "menarik", yakni sebagai berikut.

$\begin{array}{lc}\text { betek } & \text { 'tarik' } \\ \text { entek } & \text { 'tarik } \\ \text { oros } & \text { 'seret' }\end{array}$

Leksem betek 'tarik' memiliki komponen makna gerakan tangan menjulur ke arah depan kemudian kembali ke arah belakang + sasaran dalam cakupan jari tangan + motivasi menggerakkan sasaran secara perlahan. Penggunaannya dalam bahasa Sasak dialek ngeno-ngene sebagai berikut.

Sai betek kelambi ku beruk?

'Siapa yang menarik bajuku tadi?'

Leksem entek 'tarik' memiliki komponen makna gerakan tangan menjulur ke arah depan kemudian kembali ke arah belakang + sasaran dalam cakupan jari tangan (genggaman) + motivasi menggerakkan sasaran secara cepat/kuat. Contoh penggunaannya dalam bahasa Sasak dialek ngeno-ngene sebagai berikut.

Entek tali ini dengan mek dua!

'Tarik tali itu berdua!'

Leksem oros 'seret' memiliki komponen makna gerakan tangan ke arah depan dan ke arah belakang + sasaran dalam cakupan jari + sebagian sasaran berada di bawah (tanah/objek lain) + motivasi menggerakkan sasaran secara perlahan. Berikut contoh penggunaannya dalam bahasa Sasak dialek ngeno-ngene.

Oros be ngkan pindah lemari ini, sengak iye berat.

'Seret saja cara memindahkan lemari itu, karena ia berat.'

Submedan makna aktivitas tangan untuk "menarik" dalam bahasa Sasak dialek ngeno-ngene di Desa Labuhan Haji memiliki tiga leksem. Leksem betek 'tarik' menjadi leksem superordinat dalam kelompok ini. Ciri semantik yang dimiliki kelompok ini ialah adanya komponen makna tangan menjulur ke arah 
depan kemudian kembali ke arah belakang + sasaran dalam cakupan jari tangan + motivasi menggerakkan sasaran secara perlahan.

12) Medan makna aktivitas tangan "menekan"

Medan makna aktivitas tangan menekan memiliki komponen makna gerakan tangan atau jari-jari tangan + sasaran dalam cakupan + motivasi memberikan tekanan. Medan makna "menekan" dalam bahasa Sasak dialek ngenongene ialah sebagai berkut.

$\begin{array}{ll}\text { enjek } & \text { 'tekan' } \\ \text { peset } & \text { 'pijit' } \\ \text { urut } & \text { 'urut' }\end{array}$

Leksem enjek 'tekan' memiliki komponen makna gerakan tangan (ibu jari, telunjuk dan telapak tangan) + sasaran dalam cakupan + motivasi memberikan tekanan. Berikut contoh penggunaannya dalam bahasa Sasak dialek ngeno-ngene.

Coba' mek enjekang ite ban motor ino, sangne kempes.

'Coba kamu tekankan dulu saya ban motor itu, mungkin kempes.'

Leksem peset 'pijit' memiliki komponen makna gerakan tangan (seluruh jari dan telapak tangan) + ketercakupan sasaran + motivasi memberikan tekanan pada sasaran. Berikut contoh penggunaannya dalam bahasa Sasak dialek ngeno-ngene.

Pesetang Ibu nae ne juluk tono!

'Pijitin Ibu kakinya dulu sana.'

Leksem urut 'urut' memiliki komponen makna gerakan ibu jari secara berulang-ulang + sasaran dalam cakupan + motivasi memberikan tekanan secara perlahan sampai tekanan yang kuat. Berikut contoh penggunaannya dalam bahasa Sasak dialek ngeno-ngene.

Alet ngurutang amaq naena siq keseleo' ino leq dalem kamar.

'Alet mengurut kaki bapak yang keseleo itu di dalam kamar.'

Submedan makna aktivitas tangan untuk "menekan" dalam bahasa Sasak dialek ngeno-ngene di Desa Labuhan Haji memiliki tiga leksem. Leksem enjek 'tekan' menjadi leksem superordinat dalam kelompok ini. Ciri semantik yang dimiliki kelompok ini ialah adanya komponen makna gerakan tangan (ibu jari, telunjuk dan telapak tangan) + sasaran dalam cakupan + motivasi memberikan tekanan. 
13) Medan makna aktivitas tangan "menyakiti"

Medan makna aktivitas tangan "menyakiti" memiliki komponen makna gerakan tangan + sasaran + adanya motivasi untuk memberikan rasa sakit pada lawan. Medan makna untuk "menyakiti" dalam bahasa Sasak dialek ngeno-ngene terdiri dari beberapa leksem, di antaranya sebagai berikut.

$\begin{array}{ll}\text { tempelek } & \text { 'tampar' } \\ \text { tepek } & \text { 'pukul' } \\ \text { getok } & \text { 'jitak' } \\ \text { punggut } & \text { 'jambak' } \\ \text { lecok } & \text { 'colok' } \\ \text { jeltik } & \text { 'selentik' } \\ \text { plenges } & \text { 'tarik' } \\ \text { pekok } & \text { 'cekik' } \\ \text { tekik } & \text { 'cubit' } \\ \text { piles } & \text { 'dicubit' } \\ \text { jagur } & \text { 'tinju' } \\ \text { padek } & \text { 'pukul' } \\ \text { keramek } & \text { 'cakar' }\end{array}$

Leksem tempelek 'tampar' memiliki komponen makna gerakan tangan dengan melayangkan telapak tangan + sasaran (bagian wajah manusia) + motivasi untuk memberikan rasa sakit pada lawan + dilakukan dengan kuat. Berikut contoh penggunaannya dalam bahasa Sasak dialek ngeno-ngene.

Tedok anta, tempelek ku ante bareh!

'Diam kamu, kutampar kamu nanti!'

Leksem tepek 'pukul' memiliki komponen makna gerakan tangan dengan jari-jari terbuka + dipukulkan pada sasaran + sasaran (bagian tangan, paha dan punggung + motivasi memberikan rasa sakit pada sasaran. Berikut penggunaannya dalam bahasa Sasak dialek ngeno-ngene.

Ndek mek tao ngolo bareh tepek ku so impeng mek.

'Kamu tidak bisa diam nanti ku pukul juga pahamu.'

Leksem getok 'jitak' memiliki komponen makna gerakan tangan yang berbentuk buku tangan dikepal + ditekukkan + sasaran spesifik, yaitu kepala + motivasi untuk memberikan rasa sakit. Berikut contoh penggunaannya dalam bahasa Sasak dialek ngeno-ngene.

Otak leq Udin te getok siq leq Suar.

'Kepala si Udin dijitak si Suar.' 
Leksem punggut 'jambak' memiliki komponen gerakan jari tangan + sasaran dalam cakupan genggaman + sasaran pada bagian kepala, yakni rambut + sasaran ditarik dan digoyangkan + motivasi memberikan rasa sakit. Berikut contoh penggunaannya dalam bahasa Sasak dialek ngeno-ngene.

Kanak nine siq besual ino saling punggut.

'Perempuan yang berkelahi itu saling menjambak.'

Leksem lecok 'colok' memiliki komponen makna gerakan tangan. yakni jari telunjuk + sasaran yakni mata + motivasi memberikan rasa sakit. Berikut contoh penggunaannya di dalam bahasa Sasak dialek ngeno-ngene.

Ye lecok mata kakane ngonek klemak.

'Dia mencolok mata kakaknya tadi pagi.'

Leksem jeletik 'selentik' memiliki komponen makna gerakan tangan yang dilakukan menggunakan belakang jari tangan yang dibidaskan dengan ibu jari + sasaran, yakni daun telinga + motivasi memberikan rasa sakit. Berikut contoh penggunaannya dalam bahasa Sasak dialek ngeno-ngene.

Jeletikne telingaku onek klemak siq kanak ino.

'Diselentiknya telingaku tadi pagi oleh anak itu.'

Leksem plenges 'tarik' memilki komponen makna gerakan jempol dan jari telunjuk + sasaran dalam cakupan (sasaran spesifik, yakni daun telinga) + tarikan + motivasi memberikan rasa sakit. Berikut contoh penggunaannya dalam bahasa Sasak dialek ngeno-ngene.

Plengesne ite siq ibu guru ngonek.

'Ditariknya daun telingaku oleh ibu guru tadi.'

Leksem pekok 'cekik' memiliki komponen makna gerakan tangan, yakni jari-jari tangan + sasaran spesifik, yakni leher dan dalam cakupan jari tangan + motivasi untuk memberikan rasa sakit. Berikut contoh penggunaannya dalam bahasa Sasak dialek ngeno-ngene.

Pekokne aku siq loq Kadri ngonek klemak.

'Aku dicekik oleh si Kadri tadi pagi.'

Leksem tekik 'cubit' memiliki komponen makna gerakan jari tangan, yakni ujung ibu jari dan ujung jari telunjuk + sasaran (bagian paha) dalam cakupan + sasaran dijepit dan ditarik + motivasi untuk memberikan rasa sakit. 
Nendek tekik adik mek.

'Jangan kamu cubit adikmu.'

Leksem piles 'cubit' memilki komponen makna gerakan ibu jari dan jari telunjuk menjepit, menarik, dan memutar sasaran secara bersamaan + sasaran (pada bagian tubuh umumnya paha) dalam cakupan + motivasi untuk memberikan rasa sakit. Berikut contoh penggunaaannya dalam bahasa Sasak dialek ngeno-ngene.

Piles ku impeng mek bareh jaq.

'Nanti ku cubit juga pahamu.'

Leksem jagur 'tinju' memiliki komponen makna gerakan tangan dengan bentuk jari digenggam + dipukulkan + sasaran (pada bagian tubuh mana saja) + motivasi untuk memberi rasa sakit. Berikut contohnya dalam bahasa Sasak dialek ngeno-ngene.

Nendek mek jagur tian adik mek.

'Jangan kamu tinju perut adik mu.'

Leksem padek 'pukul' memiliki komponen makna gerakan tangan menggenggam objek/alat + dipukulkan + sasaran (pada bagian tubuh mana saja) + motivasi memberikan rasa sakit. Berikut contoh penggunaannya dalam bahasa Sasak dialek ngeno-ngene.

Padek be sai-sai siq marang ribut.

'Pukul siapa saja yang ribut.'

Leksem keramek 'cakar' memiliki komponen gerakan tangan, yakni ujung jari beserta kukunya + dikibaskan kepada sasaran (sasaran pada bagian kepala, yakni wajah) + memberikan bekas pada sasaran + motivasi untuk memberikan rasa sakit/melukai. Berikut contoh penggunaannya dalam bahasa Sasak.

Sangkepne bedarak te cakar siq meong ino.

'Pipinya berdarah dicakar oleh kucing itu.'

Submedan makna aktivitas tangan untuk "menyakiti" dalam bahasa Sasak dialek ngeno-ngene di Desa Labuhan Haji memiliki tiga belas leksem. Submedan makna aktivitas tangan ini tidak mempunyai leksem superordinat (superordinat zero). Ciri semantik leksem-leksem yang tergabung dalam kelompok ini ialah adanya komponen gerakan tangan + sasaran + motivasi memberi rasa sakit. 
14) Medan makna aktivitas tangan "menghancurkan"

Medan makna aktivitas tangan "menghancurkan" memiliki komponen makna gerakan tangan (jari tangan) + sasaran dalam cakupan + motivasi untuk menghancurkan. Medan makna aktivitas tangan untuk menghancurkan dalam bahasa Sasak dialek ngeno-ngene ialah sebagai berikut.

$\begin{array}{ll}\text { remes } & \text { 'remas' } \\ \text { amok } & \text { 'campur' } \\ \text { tuja' } & \text { 'tumbuk' }\end{array}$

Leksem remes 'remas' memiliki komponen makna gerakan keseluruhan jari tangan dengan mengepal dan menekan sasaran + sasaran dalam cakupan + sasaran bersifat lunak + motivasi menghancurkan sasaran. Berikut contoh penggunaannya dalam bahasa Sasak dialek ngeno-ngene.

Nendek remes kertas ini agekne tetep bagus.

'Jangan remas kertas itu agar tetap bagus.

Leksem amok 'campur' memiliki komponen gerakan tangan dengan menggunakan semua jari dan telapak tangan terbuka + sasaran bersifat lunak + motivasi mencampur/menggabungkan sasaran dengan sasaran lainnya. Berikut adalah contoh penggunaannya dalam bahasa Sasak dialek ngeno-ngene.

Amok tepeng kance telok ini, te kadu miak jaja.

'Campur tepung dan telur itu, kita gunakan untuk membuat kue.'

Submedan makna aktivitas tangan untuk "menghancurkan" dalam bahasa Sasak dialek ngeno-ngene di Desa Labuhan Haji memiliki tiga leksem. Ketiga leksem tersebut dalam kelompok ini tidak memiliki leksem superordinat, akan tetapi memiliki makna yang hampir bersinggungan. Kelompok ini termasuk ke dalam leksem superordinat zero. Ciri semantik dalam kelompok ini ialah adanya komponen makna gerakan tangan (jari tangan) + sasaran dalam cakupan + motivasi menghancurkan sasaran.

15) Medan makna aktivitas tangan "menggulung"

Medan makna aktivitas tangan "menggulung” memiliki komponen makna, yakni gerakan jari tangan + sasaran berbentuk lembaran + motivasi untuk menjadikan sasaran menjadi bulat memanjang. Bahasa Sasak dialek ngeno-ngene memiliki medan makna aktivitas tangan untuk menggulung, yakni sebagi berikut. 
$\begin{array}{ll}\text { lekut } & \text { 'gulung' } \\ \text { pilit } & \text { 'gulung, pilin, linting' }\end{array}$

Leksem lekut 'gulung' memiliki komponen makna aktivitas tangan, yakni gerakan tangan memegang sasaran + sasaran dalam cakupan + sasaran berupa lembaran atau benda-benda besar + motivasi menjadikan sasaran bulat memanjang. Contoh pemakaiannya dalam bahasa Sasak dialek ngeno-ngene sebagai berikut.

Inaq sengkane lekut tipar leq kamarne.

'Ibu sedang menggulung tikar di kamarnya.'

Leksem pilit 'gulung, pilin, linting' memiliki komponen makna gerakan tangan dengan telapak terbuka + sasaran dalam cakupan + sasaran merupakan benda-benda kecil (seperti tembakau) + dilakukan secara berulang + motivasi menjadikan sasaran menjadi bulat dan memanjang. Berikut contoh penggunaannya dalam bahasa Sasak dialek ngeno-ngene.

Papuk sengkane milit tembako leq lelambur.

'Kakek sedang melinting tembakau di teras.'

Submedan makna aktivitas tangan untuk "menggulung" dalam bahasa Sasak dialek ngeno-ngene di Desa Labuhan Haji memiliki dua leksem. Leksem lekut 'gulung' menjadi leksem superordinat dalam kelompok ini. Ciri semantik dalam kelompok ini ialah adanya komponen makna gerakan jari dan telapak tangan + sasaran dalam cakupan + motivasi menjadikan sasara bulat dan memanjang.

16) Medan makna aktivitas tangan "memanggil"

Medan makna aktivitas tangan "memanggil” memiliki komponen makna, yakni gerakan tangan + mengarah ke sasaran/objek + motivasi sebagai pemberi tanda pada sasaran/objek. Medan makna aktivitas tangan untuk "memanggil" dalam bahasa Sasak dialek ngeno-ngene hanya memilki satu leksem, yakni sebagai berikut.

uwap

'panggil'

Leksem uap 'panggil' memiliki komponen makna gerakan tangan naik dan turun + mengarah ke sasaran + motivasi sebagai pemberi tanda. Berikut contoh penggunaannya dalam bahasa Sasak dialek ngeno-ngene.

Sai jai ruene uwap aku lekan atas motor beruk.

'Entah siapa yang memanggil saya tadi dari atas motor.' 
Submedan makna aktivitas tangan untuk "memanggil" dalam bahasa Sasak dialek ngeno-ngene di Desa Labuhan Haji hanya memiliki satu leksem saja, yakni uwap 'panggil', sehingga submedan makna aktivitas tangan dalam bahasa Sasak dialek ngeno-ngene untuk 'memanggil' tidak memiliki leksem superordinat maupun leksem bawahan. Ciri semantik penggolong yang dimiliki leksem tersebut sendiri ialah adanya komponen makna gerakan tangan naik dan turun + mengarah ke sasaran + motivasi sebagai pemberi tanda.

17) Medan makna aktivitas tangan "menghadang"

Medan makna aktivitas tangan "menghadang" memiliki komponen makna, yakni merentangkan kedua lengan ke kiri dan ke kanan + sasaran + motivasi menghambat/menghentikan laju sasaran. Medan makna aktivitas tangan untuk "menghadang" dalam bahasa Sasak dialek ngeno-ngene memiliki dua leksem di antaranya sebagai berikut.

adang 'hadang'

Leksem adang 'hadang' memiliki komponen makna gerakan tangan dengan merentangkan kedua lengan ke kiri dan ke kanan + sasaran + motivasi untuk menghentikan laju sasaran. Berikut contoh penggunaannya dalam bahasa Sasak dialek ngeno-ngene.

Adang manek leq pengorong ino.

'Hadanglah ayam di gang itu.'

Submedan makna aktivitas tangan untuk "menghadang" dalam bahasa Sasak dialek ngeno-ngene di Desa Labuhan Haji hanya memiliki satu leksem saja, yakni adang 'hadang', sehingga submedan makna aktivitas tangan dalam bahasa Sasak dialek ngeno-ngene untuk 'memanggil' tidak memiliki leksem superordinat dan leksem bawahan. Ciri semantik penggolong yang dimiliki leksem tersebut sendiri ialah adanya komponen makna gerakan tangan dengan merentangkan kedua lengan ke kiri dan ke kanan + sasaran + motivasi untuk menghentikan laju sasaran.

18) Medan makna aktivitas tangan "menyalam"

Medan makna aktivitas tangan "menyalam" memiliki komponen makna, yakni gerakan tangan menggenggam + sasaran + motivasi menjabat tangan 
lawan/sasaran. Medan makna aktivitas tangan untuk "menyalam" dalam bahasa Sasak dialek ngeno-ngene, yakni sebagai berikut.

siarah 'salam'

Leksem siarah 'salam' memiliki komponen makna, yakni gerakan tangan menggenggam + sasaran (tangan lainnya) + motivasi menjabat tangan dan memberi hormat kepada lawan. Berikut contoh penggunaannya dalam bahasa Sasak dialek ngeno-ngene.

Uwah ke mek pada lalo siarah joq papuk mek?

'Sudahkah kalian pergi salaman ke rumah kakek kalian?'

Submedan makna aktivitas tangan untuk "menyalam" dalam bahasa Sasak dialek ngeno-ngene di Desa Labuhan Haji hanya memiliki satu leksem saja, yakni siarah 'salam', sehingga submedan makna aktivitas tangan dalam bahasa Sasak dialek ngeno-ngene untuk 'memanggil' tidak memiliki leksem superordinat dan leksem bawahan. Ciri semantik penggolong yang dimiliki leksem tersebut sendiri ialah adanya komponen makna gerakan tangan menggenggam + sasaran (tangan lainnya) + motivasi menjabat tangan dan member hormat kepada lawan.

19) Medan makna aktivitas tangan "menunjuk"

Medan makna aktivitas tangan "menunjuk" memiliki komponen gerakan tangan + jari telunjuk + mengarah kepada keberadaan sasaran + motivasi memberikan arah atau posisi objek/sasaran. Medan makna aktivitas tangan untuk “menunjuk" dalam bahasa Sasak dialek ngeno-ngene ialah sebagai berikut.

tunjek 'tunjuk'

Leksem tunjek 'tunjuk' memiliki komponen makna gerakan tangan + menggunakan jari telunjuk + mengarah kepada sasaran + motivasi untuk memberikan arah atau posisi objek/sasaran. Berikut contoh penggunaannya dalam bahasa Sasak dialek ngeno-ngene.

Coba' tunjekang ite be langan te joq Senggigi.

'Coba tunjuki saya arah jalan ke Senggigi.'

Submedan makna aktivitas tangan untuk "menunjuk" dalam bahasa Sasak dialek ngeno-ngene di Desa Labuhan Haji hanya memiliki satu leksem saja, yakni tunjek 'tunjuk', sehingga submedan makna aktivitas tangan dalam bahasa Sasak dialek ngeno-ngene untuk 'memanggil' tidak memiliki leksem superordinat dan 
leksem bawahan. Ciri semantik penggolong yang dimiliki leksem tersebut sendiri ialah adanya komponen makna gerakan tangan + menggunakan jari telunjuk + mengarah kepada sasaran + motivasi untuk membrikan arah atau posisi objek/sasaran.

\section{PENUTUP}

Berdasarkan pembahasan tersebut, maka dapat disimpulkan bahwa leksemleksem yang menyatakan aktivitas tangan dalam bahasa Sasak dialek ngeno-ngene di Desa Labuhan Haji, Kabupaten Lombok Timur memiliki lima puluh empat leksem. Leksem-leksem tersebut diklasifikasikan berdasarkan komponen makna yang dimilikinya, yakni berdasarkan tujuan aktivitas yang dilakukan oleh tangan, sehingga membentuk sembilan belas kelompok atau submedan makna. Kesembilan belas kelompok tersebut ialah 1) memegang 'entik'; 2) menangkap 'bau'; 3) menyentuh 'jolet'; 4) mengambil 'bait'; 5) membawa 'jauk'; 6) meletakkan 'tolo”; 7) memberi 'beang'; 8) menerima 'terima”; 9) membuka 'buka”; 10) menutup 'simpet'; 11) menarik 'entek'; 12) menekan 'enjek'; 13) menyakiti 'nyakitang'; 14) menghancurkan 'nyenyeda'; 15) menggulung 'lekut'; 16) memanggil 'uwap'; 17) menghadang 'adang'; 18) menyalam 'siarah'; dan 19) menunjuk 'tunjek'.

Penelitian ini diharapkan memberikan pendeskripisian makna mengenai medan makna aktivitas tangan dalam bahasa Sasak, khususnya dialek ngeno-ngene di Desa Labuhan Haji. Penelitian ini diharapkan bermanfaat bagi penelitian selanjutnya tentang bahasa daerah, khususnya bahasa Sasak. Pengkajian ini di sisi lain juga diharapkan dapat memberikan implikasi terhadap pelestarian dan pembelajaran bahasa daerah, khususnya bahasa Sasak.

\section{DAFTAR PUSTAKA}

Azhar, M. (1996). Peramputan Pelajaran Bahasa Sasak. Mataram: PT Intan Pariwara. Chaer, A. (2012). Linguistik Umum. Yogyakarta: Rineka Cipta.

Chaer, A. (2013). Pengantar Semantik Bahasa Indonesia. Jakarta: Rineka Cipta.

Johandi, L.M. (2017). "An Analysis of Sasak Syntactic Structure on the Forms of Passivization as Used in ngeno-ngene Dialect at Rarang Village of East Lombok". The Indonesian Journal of Language and Language Teaching, 2 (2), 60-81.

Kridalaksana, H. (2011). Kamus Linguistik. Jakarta: Gramedia.

Mahsun. (2006). Dialektologi Diakronis Bahasa Sasak di Pulau Lombok. Yogyakarta: Gama Media. 
(2006). Metode Penelitian Bahasa. Jakarta: PT Raja Grafindo Persada.

Moleong, J.L. (2014). Metode Penelitian Kualitatif. Bandung: PT Remaja Rosdakarya.

Paridi, K. (1996). Struktur Frasa Verba Bahasa Sasak, Sebuah Kajian Berdasarkan Teori X-Bar. Denpasar: Universitas Udayana.

Pateda, M. (2010). Semantik Leksikal. Jakarta: Rineka Cipta.

Setiyanto, E. (1997). Medan Makna Ativitas Tangan dalam Bahasa Jawa. Jakarta: Pusat Pembinaan dan Pengembangan Bahasa, Depdikbud.

Subroto, E. (2011). Pengantar Studi Semantik dan Pragmatik. Surakarta: Cakrawala Media.

Sudaryanto. (2015). Metode dan Aneka Teknik Analisis Bahasa. Pengantar Penelitian Kebudayaan Secara Linguistis. Yogyakarta: Sanata Darma University Press.

Toba, M. (2016). "Retensi Inovasi Fonologis Protobahasa Melayik pada Bahasa Melayu Tamiang". Ranah: Jurnal Kajian Bahasa, 5 (1), 87--100. https://doi.org/10.26499/rnh.v5i1.40

Verhaar, J.W.M. (2012). Asas-Asas Linguistik Umum. Yogyakarta: Gadjah Mada University Press. 